\title{
CHEMICAL PROPERTIES OF THE FOREST LITTER IN ISTRIA AND THE CROATIAN LITTORAL
}

\author{
ANDRIJA ŠPOLJAR ${ }^{1}$, DAMIR BARČIĆ ${ }^{2 *}$, TOMISLAVA PEREMIN VOLF ${ }^{1}$, STJEPAN \\ HUSNJAK $^{3}$, IVICA MARTINOVIĆ ${ }^{1}$
}

${ }^{1}$ College of Agriculture at Križevci, Milislava Demerca 1, 48260 Križevci, Croatia

${ }^{2}$ University of Zagreb Faculty of Forestry, Svetošimunska 25, 10000 Zagreb, Croatia; e-mail: damir.barcic@zg.htnet.hr

${ }^{3}$ University of Zagreb Faculty of Agriculture, Svetošimunska 25, 10000 Zagreb, Croatia

* Author for correspondence

\begin{abstract}
Špoljar A., Barčić D., Peremin Volf T., Husnjak S., Martinović I.: Chemical properties of the forest litter in Istria and the Croatian Littoral. Ekológia (Bratislava), Vol. 33, No. 3, p. 242-251, 2014.

The experiment was set up in the forest ecosystem with diverse vegetation zones in the area of Istria and the Croatian Littoral. Research included the following systematic soil units: lithic leptosols, rendzic leptosols, rendzic leptosols - eroded, mollic leptosols, chromic cambisol and chromic luvisols. The average quantity of the forest litter in the studied systematic soil units reaches 13.36 t/ha (Tables 1-3). The "wealth" of organic matter in the studied soil units can be presented with the following series: chromic cambisols $(\mathrm{CMx})>$ mollic leptosols (LPm), organogenic, rendzic leptosols $(\mathrm{LPk})>$ lithic leptosols $(\mathrm{LPq})>$ chromic cambisols $(\mathrm{CMx})$ - Terra rossa, chromic luvisols $(\mathrm{LVx})>$ rendzic leptosols $(\mathrm{LPk})$ - eroded. As expected, the lowest value of total nitrogen was found in the lithic leptosols in relation to almost all the other soils, except when compared with chromic cambisol and rendzic leptosols $(p<0.05)$. The statistically justified higher values of the percentage share of $\mathrm{P}_{2} \mathrm{O}_{5}$ in the forest litter were found in chromic luvisols and rendzic leptosols - eroded in relation to the other studied soils. Significantly higher level of copper contamination was inside rendzic leptosols - eroded in relation to the other studied soils. The exception is rendzic leptosols $(p<0.05)$. A significantly higher zinc content was detected in the lithic leptosols in relation to the other soil units, except for chromic luvisols, while a justifiably higher total lead and cadmium content in the forest litter was observed in chromic luvisols in relation to the other compared soils $(p<0.05)$.
\end{abstract}

Key words: contamination, heavy metals, soil units.

\section{Introduction}

According to Martinović (2003), the forest floor has a geochemical role and represents an important factor in the exchange of matter between the vegetation, soil and atmosphere. It is a natural organic fertilizer rich in all the nutritive elements in those quantities and ratios that are required by forest trees. The forest floor plays an important part in the regulation of hydrological conditions in the soil. It decreases evaporation and increases the infiltrative 
capacity of precipitation water, as well as acts favourably on soil temperature relations. In the words of Topić (1992), the quantity and structure of the forest floor are measurable indicators of the degree of meliorativity of a particular forest species. The author estimates that the quantity of the forest floor in cultures of black pine is between 8.1 and $22.1 \mathrm{lt} / \mathrm{ha}$, while the values of the floor chemism amount to $0.17 \%$ for potassium and $0.07 \%$ for phosphorus.

According to Mayer (1992), the soils of the littoral karst in Croatia are an irreplaceable natural resource which should be maximally protected from erosion-induced damage. It is for this reason that autochthonous forest vegetation should be favoured and that soil damaged by erosion processes should be afforested. An indented landscape with a strong relief energy, high precipitation amounts, strong winds and insolation direct the pedogenesis toward the initial developmental stages. The dominant systematic soil units in the structure of the soil cover are as follows: lithic leptosols, rendzic leptosols, rendzic leptosols - eroded, mollic leptosols, chromic cambisols and chromic luvisols (Bogunović et al., 2002; Martinović, 2003).

Surface stoniness and rockiness often contribute to low estimates of soil productivity, which reflects negatively on more intensive afforestation operations. The abandonment of agriculture in cultivated surfaces and terraces in the coastal region encourages the expansion of forest vegetation over highly fertile soils. Numerous pine cultures successfully ameliorate stony areas, but are particularly susceptible to fires, after which the organic matter content in the soil decreases dramatically, soil chemism changes, the forest floor is destroyed, the clay content increases and a path to erosion is opened (Martinović, Kovačević, 1984).

According to Husnjak (2005), erosion processes frequently erode the humus-accumulative and deeper horizons, which may lead to a complete loss of some important soil functions. In this sense, and to highlight the non-commercial role of the forest ecosystem, Tikvić and Seletković (2003) stress the primary importance of the hydrological and anti-erosion role of the forest floor. At the same time, the micro-climatic conditions in the forest ecosystem are an important factor in the transformation process (mineralisation and humification) of the forest floor. In view of the above, all forest management measures should take account of the condition and changes in the forest floor (Martinović, 2003).

Fuqiang et al. (2010) states that concentrations of total nitrogen, phosphorus and humus are a clear indicator of the forest floor quality. In addition to the quality of the forest floor, which guarantees mutually balanced relations in the forest ecosystem, factors that might have an adverse effect on it should also be mentioned. One of these factors is the degree of contamination of the forest floor with heavy metals.

According to Čoga (2005), the spatial distribution of the atmophilic Pb-Zn-As-Cd-P association of elements is generally directly linked to the sharp climatic boundary which stretches along the ridge of the littoral mountain chain of north-western Croatia. Aerosols borne by western winds from regional (SE Italy), but also local (oil industry in Rijeka, thermal power station in Plomin) pollutants are deposited along this regional climatic barrier. In the Risnjak National park area, as many as $20 \%$ of the samples are polluted with lead, whereas the entire area of western Croatia has less than $3 \%$ of lead-polluted samples. In the area from Istria to Dubrovnik, the author recorded higher quantities of total heavy metals on a carbonate base in relation to the soils developed on non-carbonate clastic rocks or alluvial sediments. 
The survey of available literature sources shows that the authors mainly treat erosion processes and their impact on the soil, as well as the nutritive potential of the forest floor, but much less so its pollution with heavy metals. For this reason, research conducted in the area of Istria and Primorje, in addition to determining the basic chemical features, also encompassed the identification of total copper, zinc, lead and cadmium content in the forest floor.

The purpose of this paper is to determine the value of the forest floor in different systematic soil units in Istria and Primorje in terms of the forest floor and humus quantity, total nitrogen content, $\mathrm{P}_{2} \mathrm{O}_{5}$ and $\mathrm{K}_{2} \mathrm{O}$ and total heavy metal content (copper, zinc, lead, cadmium) in the organic matter. In order to determine the quality of the forest floor, the above mentioned chemical features were compared by systematic soil units. The calculation of the degree of pollution with heavy metals will provide an insight into the possible pollution of the forest floor.

\section{Material and methods}

Research was conducted in the forest ecosystem in different vegetation zones in the area of Istria and the Croatian Littoral. The systematic soil units include lithic leptosols, rendzic leptosols, rendzic leptosols - eroded, mollic leptosols, chromic cambisols, chromic cambisols (Terra rosss) and chromic luvisols. The experiment was set up in 50 plots (plot surface $625 \mathrm{~m}^{2}$ ) in stands of black pine, of which 43 were established in forest cultures and 7 in natural stands. The plots were selected according to the age criterion (stands aged over 40) and with varying risks in terms of erosion processes (Husnjak, 2005) and of possible contamination of the investigated soil units with heavy metals. The typological soil units were determined according to the valid soil classification in the Republic of Croatia (Škorić et al., 1985). Figure 1-4 presents the research area and the sample plots in which the soil was sampled.

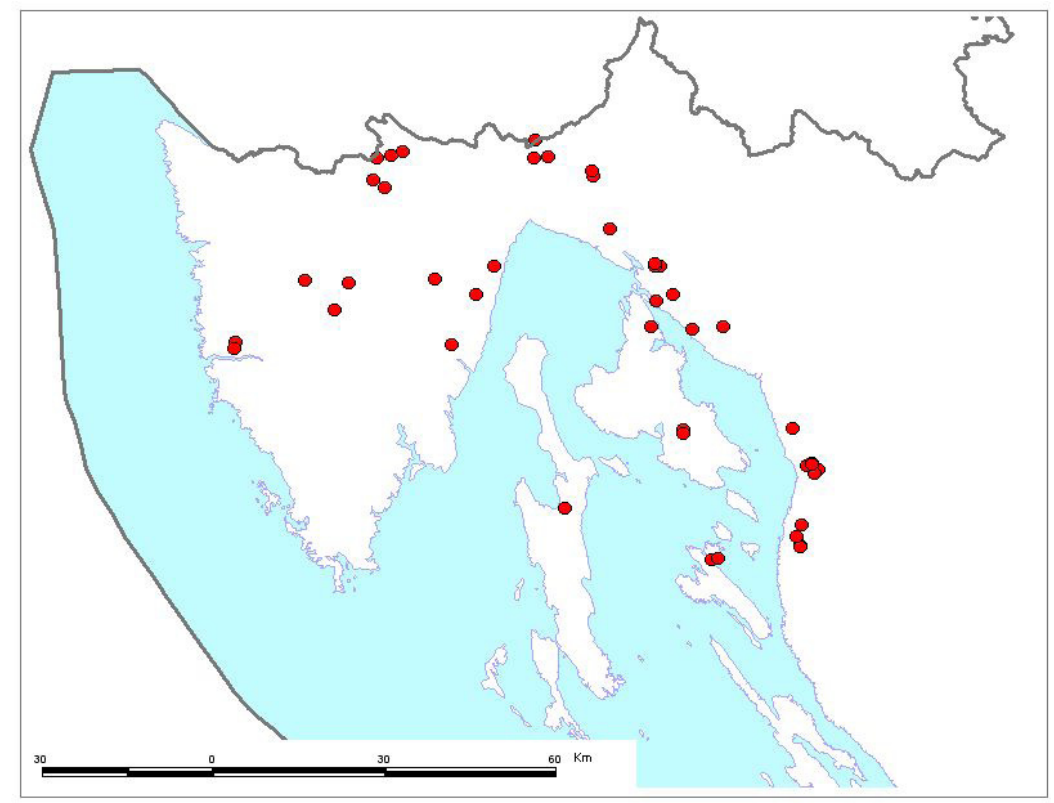

Fig. 1. Experimental plots on the research area in Croatia. 


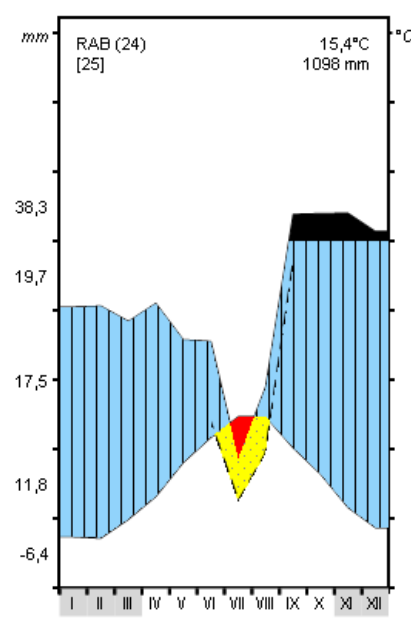

Fig. 2. Climatodiagram for the island of Rab according to Walter (1955) in period from 1981 to 2005 .

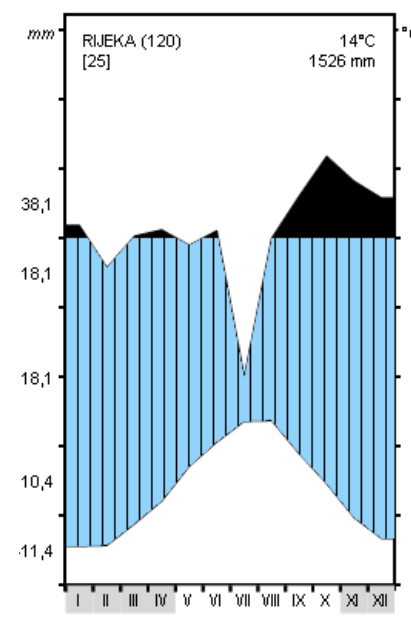

Fig. 3. Climatodiagram for Rijeka according to Walter (1955) in period from 1981 to 2005 .

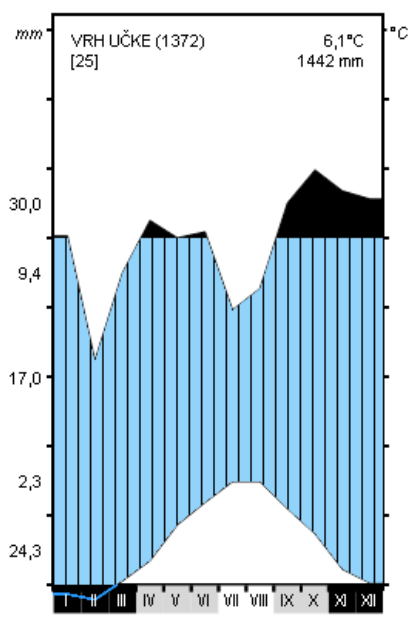

Fig. 4. Climatodiagram for Učka according to Walter (1955) in period from 1981 to 2005 .

The samples of the humus-accumulative horizon were formed from five individual samples within a sample plot. They were taken for the purpose of determining soil reaction, humus quantity and total nitrogen content, as well as the $\mathrm{C} / \mathrm{N}$ ratio. To calculate the quantity of the forest floor, three samples were taken $(25 \times 25 \mathrm{~cm})$ along the sample plot diagonally. Pedological research methods correspond to the generally accepted standards. The following chemical soil analyses were performed: humus quantity according to Thurin, total nitrogen content according to Kjeldahl (ISO 11261:2004), soil reaction in $\mathrm{H}_{2} \mathrm{O}$ (ISO 10390:2005), total $\mathrm{P}_{2} \mathrm{O}_{5}$ and $\mathrm{K}_{2} \mathrm{O}$ in the organic matter by means of wet combustion with nitric acid, as well as total copper, zinc, lead and cadmium content by means of the AAS method (ISO 11047:2004). The degree of contamination (DC) was calculated in the forest floor (NN 32/10) for total copper, zinc, lead and cadmium content using maximally allowed values of these heavy metal contents for lighter and skeletal soils or soils poorer in humus, and for heavier and heavy soils or soils richer in humus (Eikman, Kloke, 1991). Pedological data were compared in terms of the studied systematic soil units by means of variance analysis $(p<0.05)$, using the STATSOFT, INC. (2003) computer programme.

\section{Results}

\section{Climatic conditions in the research area}

The research area of Istria and the Croatian Littoral is predominantly represented by moderate warm rainy climate ' $\mathrm{C} f \mathrm{~s} a x$ ", characterized by hot summers and mean monthly temperatures above $22^{\circ} \mathrm{C}$ (Seletković, Katušin, 1992). The winter rainy period is broadly distributed in the spring and autumn-winter maximum, while the driest part of the year occurs in the warm season. The research area, i.e. sample plots, mainly comprise the sub-Mediterranean and eu-Mediterranean zone. The annual trend of mean monthly air temperatures and monthly precipitation quantities for these zones is presented in the climatic diagrams for Rab, Rijeka and Učka in Figures 2-4. In terms of phytogeographic distribution, the study area comprises the Mediterranean region, which is divided into two vegetation belts and five vegetation zones (Trinajstić, 1986). 


\section{Chemical properties of the soil}

The following systematic soil units were identified in the sample plots: lithic leptosol (LPq), rendzic leptosol (LPk), rendzic leptosol (LPk) - eroded, mollic leptosol (LPm), chromic cambisol (CMx), chromic cambisol (CMx) - Terra rossa and chromic luvisol (LVx) according to the FAO classification (1990) and Špoljar (1999), and according to the set correlation relations in the Republic of Croatia (Škorić et al., 1985). Table 1 shows the average quantities of the forest floor per systematic soil units under study. The highest quantities of organic matter (15.89 t/ha) were recorded in chromic cambisols, while rendzic leptosols contained the lowest quantities (7.66 t/ha). Based on research results, the 'wealth' of the studied systematic soil units in organic matter can be presented in the following series: chromic cambisols $(\mathrm{CMx})>$ mollic leptosols $(\mathrm{LPm})$, rendzic leptosols $(\mathrm{LPk})>$ lithic leptosols $(\mathrm{LPq})>$ chromic cambisols $(\mathrm{CMx})$ - Terra rossa $>$ chromic luvisols $(\mathrm{LVx})>$ rendzic leptosols (LPk) - eroded, (unfavourable position in the relief). The degree of contamination (DC) with heavy metals by systematic soil units is given in Table 2 .

$\mathrm{T}$ a b l e 1. Average amount of forest litter according to research soil unit.

\begin{tabular}{|l|c|c|c|c|c|c|c|}
\hline Soil unit & $\begin{array}{c}\text { Lithic } \\
\text { leptosols }\end{array}$ & $\begin{array}{c}\text { Rendzic } \\
\text { leptosols }\end{array}$ & $\begin{array}{c}\text { Rendzic } \\
\text { leptosols } \\
\text {-eroded }\end{array}$ & $\begin{array}{c}\text { Mollic } \\
\text { leptosols }\end{array}$ & $\begin{array}{c}\text { Chromic } \\
\text { cambisols }\end{array}$ & $\begin{array}{c}\text { Chromic } \\
\text { cambisols- } \\
\text { Terra rossa }\end{array}$ & $\begin{array}{c}\text { Chromic } \\
\text { luvisols }\end{array}$ \\
\hline $\begin{array}{l}\text { Amount of forest } \\
\text { litter, t/ha }\end{array}$ & 11.01 & 11.96 & 7.66 & 12.49 & 15.89 & 9.55 & 8.94 \\
\hline
\end{tabular}

T a b le 2. Contamination degree (So) of forest litter with copper, zinc, lead and cadmium (NN 32/10).

\begin{tabular}{|l|c|c|c|c|}
\hline \multirow{2}{*}{ Soil unit } & \multicolumn{3}{|c|}{ Contamination degree, So, \% } \\
\cline { 2 - 5 } & $\mathbf{C u}$ & $\mathbf{Z n}$ & $\mathbf{P b}$ & Cd \\
\hline Lithic leptosols & 17.2 & 20.3 & 4.4 & 13.0 \\
\hline Rendzic leptosols & 18.3 & 18.7 & 4.3 & 4.0 \\
\hline Rendzic leptosols - eroded & 18.7 & 17.2 & 3.3 & 4.0 \\
\hline Mollic leptosols & 17.3 & 18.3 & 3.8 & 5.0 \\
\hline Chromic cambisols & 17 & 18.4 & 4.5 & 13.0 \\
\hline Chromic cambisols - Terra rossa & 16.8 & 18.9 & 3.9 & 5.0 \\
\hline Chromic luvisols & 15.7 & 2.0 & 5.3 & $32.0^{\mathrm{II}}$ \\
\hline
\end{tabular}

Notes: So- contamination degree So < 25 - I class, So 25 - 50\% - II class, So 50 - 100\% - III class, So 100 - 200\% - IV class, So $>200 \%-$ V class.

Calculations of the degree of contamination for the organic soil cover according to the criteria provided by Eikman and Kloke (1991) showed that the first class of soil contamination $(\mathrm{DC}<25 \%)$ was recorded for chromic cambisols $(\mathrm{CMx})$, rendzic leptosols (LPk), mollic leptosols (LPm), lithic leptosols (LPq), chromic cambisols (CMx) - Terra rossa and rendzic leptosols $(\mathrm{LPm})$ - eroded; in other words, no contamination with any investigated heavy metal was found. The forest floor of chromic luvisols ( $\mathrm{LVX}$ ) has higher levels of cadmium 
contamination ( $\mathrm{DC}=32 \%)$. The reason probably lies in geolithogens, although the possibility of anthropogenic emission cannot be excluded. The results of statistical analysis of the examined chemical properties of the organic soil cover are given in Table 3. Significantly higher values of soil reaction measured in water were found in mollic leptosols (LPm) and rendzic leptosols (LPk) - eroded, in relation to the other investigated soil units. The justifiably lower value was found in chromic luvisols ( $\mathrm{LVx})$ and chromic cambisols (CMx) - Terra rossa $(p<0.05)$. The statistically justified higher values of humus quantities were found in rendzic leptosols - eroded, in relation to the other investigated soils, except in relation to rendzic leptosols (LPk) $(p<0.05)$. In line with expectations, a significantly lower value of total nitrogen content was found in lithic leptosols $(\mathrm{LPq})$ in relation to almost all the other soils, except for chromic cambisols $(\mathrm{CMx})$ and rendzic leptosols ( $\mathrm{LPk})(p<0.05)$. The statistically justified higher values of the percentage share of $\mathrm{P}_{2} \mathrm{O}_{5}$ in the forest floor were found in chromic cambisols (CMx) - Terra rossa and rendzic leptosols (LPk) - roded, compared to all the other investigated soil units; the same relates to the percentage share of $\mathrm{K}_{2} \mathrm{O}$ in chromic luvisols $(\mathrm{LVx})$ in relation to the other soils, except in relation to rendzic leptosols (LPk) $(p<0.05)$, where there were no justifiable differences $(p<0.05)$.

A significantly higher total copper content in the forest floor was found in rendzic leptosols, eroded, in relation to all the other soils, except in rendzic leptosols $(p<0.05)$. A significantly higher zinc content was found in lithic leptosols (LPq) compared to the other soil units, except for chromic luvisols (LVx), while a justifiably higher content of total lead and cadmium in the forest floor was obtained in chromic luvisols in relation to the other soils $(p<0.05)$.

T a b l e 3. Results of chemical properties of the organic soil cover.

\begin{tabular}{|c|c|c|c|c|c|c|c|c|c|}
\hline \multirow[t]{2}{*}{ Soil unit } & \multirow[t]{2}{*}{$\begin{array}{l}\mathrm{pH}, \\
\mathrm{H}_{2} \mathrm{O}\end{array}$} & \multirow[t]{2}{*}{$\begin{array}{l}\text { Humus, } \\
\mathrm{g} \mathrm{kg}^{-1}\end{array}$} & \multirow[t]{2}{*}{$\begin{array}{c}\mathrm{N} \\
\mathrm{g} \mathrm{kg}^{-1}\end{array}$} & \multicolumn{2}{|c|}{$\begin{array}{l}\text { amount, } \\
\%\end{array}$} & \multicolumn{4}{|c|}{$\begin{array}{l}\text { Total amount of heavy metals, } \\
\text { mg kg-1 }\end{array}$} \\
\hline & & & & $\mathrm{P}_{2} \mathrm{O}_{5}$ & $\mathrm{~K}_{2} \mathrm{O}$ & $\mathrm{Cu}$ & $\mathrm{Zn}$ & $\mathrm{Pb}$ & Cd \\
\hline Lithic leptosols & $6.94^{\mathrm{b}}$ & $2.98^{\mathrm{c}}$ & $0.16^{\mathrm{c}}$ & $4.55^{\mathrm{b}}$ & $8.12^{\mathrm{bc}}$ & $10.30^{c}$ & $40.53^{\mathrm{a}}$ & $4.38^{\mathrm{b}}$ & $0.13^{\mathrm{b}}$ \\
\hline Rendzic leptosols & $6.95^{\mathrm{b}}$ & $4.10^{\mathrm{ab}}$ & $0.20^{\mathrm{bc}}$ & $5.23^{\mathrm{b}}$ & $8.83^{\mathrm{ab}}$ & $10.97^{\mathrm{ab}}$ & $37.38^{\mathrm{c}}$ & $4.29^{\mathrm{bc}}$ & $0.04^{\mathrm{b}}$ \\
\hline Rendzic leptosols - eroded & $7.60^{\mathrm{a}}$ & $4.41 \mathrm{a}$ & $0.24^{\mathrm{ab}}$ & $6.78^{\mathrm{a}}$ & $8.12^{\mathrm{bc}}$ & $11.19^{\mathrm{a}}$ & $34.25^{\mathrm{d}}$ & $3.29^{\mathrm{e}}$ & $0.04^{\mathrm{b}}$ \\
\hline Mollic leptosols & $7.39^{\mathrm{a}}$ & $3.60^{\mathrm{b}}$ & $0.24^{\mathrm{ab}}$ & $4.84^{\mathrm{b}}$ & $7.10^{\mathrm{d}}$ & $10.43^{\mathrm{bc}}$ & $36.54^{\mathrm{cd}}$ & $3.83^{\mathrm{d}}$ & $0.05^{\mathrm{b}}$ \\
\hline Chromic cambisols & $6.84^{\mathrm{b}}$ & $3.35^{c}$ & $0.20^{\mathrm{bc}}$ & $4.78^{\mathrm{b}}$ & $8.00^{c}$ & $10.24^{\mathrm{c}}$ & $36.78^{c}$ & $4.52^{\mathrm{b}}$ & $0.13^{\mathrm{b}}$ \\
\hline $\begin{array}{l}\text { Chromic cambisols } \\
\text { - Terra rossa }\end{array}$ & $6.38^{\mathrm{c}}$ & $3.24^{\mathrm{c}}$ & $0.24^{\mathrm{ab}}$ & $6.80^{\mathrm{a}}$ & $7.15^{\mathrm{d}}$ & $10.14^{\mathrm{c}}$ & $37.93^{\mathrm{bc}}$ & $3.88^{\mathrm{cd}}$ & $0.05^{\mathrm{b}}$ \\
\hline Chromic luvisols & $5.90^{c}$ & $3.48^{\mathrm{c}}$ & $0.25^{\mathrm{a}}$ & $4.67^{\mathrm{b}}$ & $9.04^{\mathrm{a}}$ & $9.37^{\mathrm{d}}$ & $39.82^{\mathrm{ab}}$ & $5.28^{\mathrm{a}}$ & $0.33^{\mathrm{a}}$ \\
\hline
\end{tabular}

Notes: ${ }^{\mathrm{a}, \mathrm{b}, \mathrm{c}, \mathrm{d}}$ Values in the same row marked by different letters differ significantly $(\mathrm{p}<0.05)$.

\section{Discussion}

The forest floor is a layer on humus or soil that consists of newly shed vegetative parts, such as needles or leaves, bark and cones, dead parts of grassy vegetation broken off from plants and other parts of the vegetation. Cones up to half their size are also treated as the forest floor (Bilandžija, 1992). According to Vitousek et al. (1995) and Berg and Meentemeyer (2001), 
the forest floor is one of the main mediums for nutrient transfer between the soil and the environment. The exchange of matter and the organic layer decomposition are conditioned by three groups of factors. These are chemical factors (chemical composition, $\mathrm{pH}$, humus, the $\mathrm{C} / \mathrm{N}$ ratio), physical factors (climatic indicators) and biotic factors (microorganisms and fauna in the soil) (Swift et al., 1979). Topić (1992) also cites the correlation between the forest floor and the degree of meliorativity. In addition to this, Barčić (2007) also points out that large quantities of the forest floor do not automatically signify a more favourable edaphic effect. The reason for this is that more arid conditions, i.e. the existence of a dry period in Mediterranean forest ecosystems, decelerate the process of the forest floor transformation. The following order of the wealth of soil units with organic matter was determined by the author's own research: chromic cambisols $(\mathrm{CMx})>$ mollic leptosols $(\mathrm{LPm})>$ rendzic leptosols $(\mathrm{LPk})>$ lithic leptosols $(\mathrm{LPq})>$ chromic cambisols $(\mathrm{CMx})-$ Terra rossa $>$ chromic luvisols $(\mathrm{LVx})>$ rendzic leptosols, $(\mathrm{LPk})$ - eroded.

The study of the forest floor has demonstrated a very strong impact of the climatic factor on its quantities and composition (Jensen, 1974; Meentemeyer et al., 1982; Starr et al., 2005; Astel et al., 2009). A positive correlation between air humidity and the total forest floor quantity is particularly distinctive (Astel et al., 2009). My own research compares this statement with soils found at higher altitudes, where a higher quantity of the forest floor was recorded (Table 1). Apart from the climatic conditions (climate), the forest floor is also influenced by stand age, tree number and density and vegetation composition and structure (Albrektson, 1988; Cuevas, Lugo, 1998; Diaz-Maroto, Vila-Lameiro, 2006). Naturally, the relief as a factor should also be taken into account, because the research area abounds in terrains with bigger or smaller slopes. Some authors relate the relief and especially precipitation amounts to the quantity of the organic cover (Santamaria, Martin, 1998). In our research, the highest amount of the organic matter, as has already been pointed out, was recorded in chromic cambisols (CMx), which can be attributed to higher altitudes at which these soils occur. The lowest quantities of the organic matter were recorded in rendzic leptosols (LPx), eroded, which are exposed to erosion processes due to their unfavourable position in the relief.

It is also important to view the value of the forest floor from the ecological aspect. Regulating the relationships in the exchange of matter has particular significance for forest ecosystems. Biogenic micro and macro elements have a decisive effect on enabling natural regeneration in the forest ecosystem and an indirect effect on ensuring productive site capacity. For this reason, the research results also present chemical properties of the forest floor (Table 3 ). According to Fuqiang et al. (2010), concentrations of total nitrogen, phosphorus and humus are clear indicators of the quality of the forest floor. In addition to the floor quality, which guarantees mutually balanced relations in the forest ecosystem, it is also vital to highlight those factors which might have an adverse effect on the forest floor. One of these is the degree of contamination of the floor with heavy metals (Table 2). The investigation recorded the first degree of soil contamination ( $\mathrm{DC}<25 \%$ ) for chromic cambisol, rendzic leptosol, mollic leptosol, lithic leptosol, chromic cambisol - Terra rossa and rendzic leptosol - eroded. No contamination with copper, zinc, lead and cadmium was recorded according to the criteria provided by Martinović (2003). According to the criteria given by Eikman and Kloke (1991), only the forest floor of chromic luvisol showed a higher degree of cadmium contamination 
( $\mathrm{DC}=32 \%)$. The most probable reason is the geolithogens, although the possibility of anthropogenic emissions is not excluded. Total heavy metal content in the soil forest floor indicated a satisfactory condition in terms of contamination (Martinović, 2011). The content of copper in the soil amounts to $5-20 \mathrm{mg} / \mathrm{kg}$ on average and corresponds to the pedogenic soil condition. In the study area, the results $(9.37 \mathrm{mg} / \mathrm{kg}$ in chromic luvisol to $11.19 \mathrm{mg} / \mathrm{kg}$ in renzdic leptosol - eroded) coincide with the results by Španjol et al. (2010), where it was found that copper concentrations in the soil were not above the limit values (Martinović, 1997, 2003) in any of the cases. Copper concentrations were somewhat higher in a shallower sampling layer due to the higher humus content.

The paper also investigated the proportion of zinc in the organic soil cover. The average zinc content in the soil according to Vukadinović and Lončarić (1998) is $5-20 \mathrm{mg} / \mathrm{kg}$, while Martinović $(1997,2003)$ records $10-50 \mathrm{mg} / \mathrm{kg}$ as a geogenic value. Our own research recorded the highest value of the total content of this heavy metal in lithic leptosol in the amount of $40.53 \mathrm{mg} / \mathrm{kg}$, which is above average, but still within the geogenic value. Španjol et al. (2010) found that the naturally acquired zinc content in the soil was above the allowed values in almost all the sampling locations from Jastrebarsko to Rijeka (Croatia).

Lead values identified in the study area ranged from $3.29 \mathrm{mg} / \mathrm{kg}$ in rendzic leptosol eroded, to $5.28 \mathrm{mg} / \mathrm{kg}$ in chromic luvisol. According to Vukadinović and Lončarić (1998), in general lead is present in all the soils in the range from 15 to $40 \mathrm{mg} / \mathrm{kg}$, while Martinović (2003) states the upper boundary of the geogenic soil condition of $10 \mathrm{mg} / \mathrm{kg}$. Contamination may increase lead levels in the soil up to several thousand milligram per kilogram. Lead remains in the soil for hundreds of years, so that the consequences of the use of some products continue to be a problem. Research by Španjol et al. (2010) showed that lead concentrations in the soil were nowhere above the limit value, which was also confirmed by our research. Still, in terms of lead contamination, the values were on average above $50 \%$ of the allowed ones (Martinović, 1997, 2003).

The natural cadmium content in the soils according to Vukadinović (1998) does not exceed the value of $1 \mathrm{mg} / \mathrm{kg}$ of the soil, while Martinović (2003) states that the naturally acquired condition of cadmium content in the soil is below $0.5 \mathrm{mg} / \mathrm{kg}$, which corresponds to our research as well (Table 3). Plants can accumulate cadmium to a significantly higher toxicity level for animal and human population without manifesting signs of phytotoxicity (Wolt, 1994). Cadmium values recorded in the study area ranged from $0.04 \mathrm{mg} / \mathrm{kg}$ for rendzic leptosol and rendzic leptosol - eroded, to $0.33 \mathrm{mg} / \mathrm{kg}$ for chromic luvisol.

\section{Conclusion}

The following conclusions can be drawn on the basis of the above:

The average quantity of the forest floor in the investigated systematic soil units amounts to $13.36 \mathrm{t} / \mathrm{ha}$. The 'wealth' of the studied soil units with organic matter can be presented by the following series: chromic cambisols $(\mathrm{CMx})>$ mollic leptosols $(\mathrm{LPm})>$ rendzic leptosols $(\mathrm{LPk})>$ lithic leptosols $(\mathrm{LPq})>$ chromic cambisols $(\mathrm{CMx})-$ Terra rossa $>$ chromic luvisols $(\mathrm{LVx})>$ rendzic leptosols $(\mathrm{LPk})$ - eroded. The highest humus quantities were recorded in rendzic leptosols - eroded, in relation to all the other studied soils, except in relation to rend- 
zic leptosols $(p<0.05)$. In line with expectations, the lowest quantity of total nitrogen was recorded in lithic leptosols in relation to almost all the soils, except for chromic cambisols and rendzic leptosols $(p<0.05)$. The statistically justified higher quantity of the percentage share of $\mathrm{P}_{2} \mathrm{O}_{5}$ in the forest floor were found in chromic cambisols - Terra rossa and rendzic leptosols - eroded, in relation to all the other soil units, and so was the percentage share of $\mathrm{K}_{2} \mathrm{O}$ in chromic luvisol in relation to all the other soils, except for rendzic leptosol, where there were no justifiable differences $(p<0.05)$. This research and the obtained results also have practical importance for forestry, because the quantities of the forest floor and the percentage content of the bioelements in it are measurable indicators which enable the assessment of the degree of meliorativity of particular forest species in relation to chemical soil fertility.

- The first class of soil contamination ( $\mathrm{DC}<25 \%)$ was recorded for chromic cambisols, rendzic leptosols, mollic leptosols, lithic leptosols, chromic cambisols - Terra rossa and rendzic leptosols - eroded; in other words, no contamination with any investigated heavy metal was recorded. A significantly higher total copper content in the forest floor was recorded in rendzic leptosols, eroded, in relation to all the other soils, except for rendzic leptosols $(p<0.05)$. Significantly higher zinc content was recorded in lithic leptosols compared to all the other soil units, except for chromic luvisols. The justifiably higher total lead and cadmium content in the forest floor was recorded in chromic luvisols in relation to all the other compared soils $(p<0.05)$.

\section{References}

Albrektson, A. (1988). Needle litterfall in stands of Pinus sylvestris L., in relation to site quality, stand age and latitude. Scand. J. For. Res., 3, 333-342. DOI: 10.1080/02827588809382521.

Astel, A., Parzych, A. \& Trojanowski J. (2009). Comparasion of litterfall and nutrient return in a Vaccinio ulignosiBetuletum pubescentis and an Empetro nigri-Pinetum forest ecosystem in northern Poland. For. Ecol. Manag., 257, 2331-2341. DOI: 10.1016/j.foreco.2009.03.026.

Barčić, D. (2007). Odnosi stanišnih čimbenika u sastojinama crnoga bora (Pinus nigra J.F. Arnold) u Hrvatskom primorju i u Istri. Disertacija, Šumarski fakultet Sveučilišta u Zagrebu.

Berg, B. \& Meentemeyer V. (2001). Litter fall in some European coniferous forests as dependent on climate: a synthesis. Can. J. For. Res., 31, 292-301. DOI: 10.1139/x00-172.

Bilandžija, J. (1992). Prirodno opterećenje sastojina alepskog, primorskog i crnog bora šumskim gorivima. Radovi, vol. 27, br. 2, Jastrebarsko, (pp. 105-113).

Bogunović, M., Vidaček, Ž. \& Husnjak S. (2002). Poglavlje u okviru potprojekta: Ekološki monitoring učinka na okoliš pošumljenih područja, saniranih požarišta te izvedenih protupožarnih putova. Projekt obnove i zaštite priobalnih šuma, IBRD br. 4119 HR. A.C.T. d.o.o.

Cuevas, E. \& Lugo A.E. (1998). Dynamics of organic matter and nutrient return from litterfall in stands often tropical tree plantation species. For. Ecol. Manag., 112, 263-279. DOI: 10.1016/S0378-1127(98)00410-1.

Čoga, L. (2005). Izvješće o stanju teških metala Agenciji za zaštitu okoliša, dio izvješća, Zagreb: Agronomski Fakultet.

Diaz-Maroto, I.J. \& Vila-Lameiro P. (2006). Litter production and composition in natural stands of Quercus robur L. (Galicia, Spain). Pol. J. Ecol., 54(3), 429-439.

Eikmann, T.H. \& Kloke A. (1991). Nutzungs und schutzbezogene orientierungswerte für (Schad) stoffe in Böden. In D. Rosenkranz, G. Bachmann, G. Einsele \& H.M. Harreß (Eds.), Bodenschutz. Berlin: Erich Schmidt Verlag.

FAO - UNESCO (1990). Soil map of the world: Revised Legend. World Soil Resources Report 60. Rome: FAO/UNESCO ISRICS.

Fuqiang, S., Xiaoxu, F. \& Ruiqing S. (2010). Review of mixed forest litter decomposition researches. Acta Ecologica Sinica, 30, 221-225. DOI: 10.1016/j.chnaes.2010.06.006.

Husnjak, S., Pernar, N., Pernar, R. \& Kisić I. (2005). Rizik od erozije tla vodom u šumskim ekosustavima Hrvatske. Šumarski List, 129(Suppl.), 69-77. 
Jensen, V. (1974). Decomposition of angiosperm tree leaf litter. In C.H. Dickinson \& G.J.R. Pugh (Eds.), Biology of plant litter decomposition (pp. 66-104). London, NY: Academic Press.

Martinović, I. (2011). Kemijske značajke šumske prostirke u mediteranskim ekosustavima. Završni specijalistički diplomski stručni rad, Visoko gospodarsko učilište u Križevcima.

Martinović, J. \& Kovačević Z. (1984). Kulturno tehnološke promjene u šumskim tlima na kršu Hrvatske. Radovi Šumarski Instituta Jastrebarsko 2, izvanredno izdanje, (pp. 115-122).

Martinović, J. (1997). Tloznanstvo u zaštiti okoliša. Priručnik za inženjere, Zagreb.

Martinović, J. (2003). Gospodarenje šumskim tlima u Hrvatskoj. Šumarski Institut, Jastrebarsko i Hrvatske šume d.o.o., Zagreb.

Mayer, B. (1992). Šumska tla Republike Hrvatske pri kraju XX. Stoljeća. In Đ. Rauš (Ed.): Šume u Hrvatskoj (pp. 19-33). Zagreb: Sveučilište u Zagrebu, Šumarski fakultet i «Hrvatske šume».

Meentemeyer, V., Box, E.O. \& Thompson R. (1982). Patterns and amounts of terrestrial plant litter. BioScience, 32, 125-128. DOI: $10.2307 / 1308565$.

Regulations on the Protection of agricultural land from contamination (NN 32/10 - Official Gazette of the Republic of Croatia).

Santamaria, J.M. \& Martin A. (1998). Influence of air pollution on the nutritional status of Navarra's forests Spain. Chemosphere, 36, 943-948. DOI: 10.1016/S0045-6535(97)10152-7.

Seletković, Z. \& Katušin Z. (1992). Klima Hrvatske. In Đ. Rauš (Ed.), Šume u Hrvatskoj (pp. 13-19). Zagreb: Sveučilište u Zagrebu, Šumarski fakultet i «Hrvatske šume».

Starr, M., Saarsalmi, A., Hokkanen, T., Merilä, P. \& Helmisaari H.S. (2005). Models of litterfall production for scots pine (Pinus sylvestris L.) in Finland using stand, site and climate factors. For. Ecol. Manag., 205, 215-225. DOI: 10.1016/j.foreco.2004.10.047.

STATSOFT, INC. (2003). Electronic statistics textbook. Tulsa, OK: StatSoft. http://www.statsoft.com/textbook/ stathome.html.

Swift, M.J., Heal, O.W. \& Anderson J.M. (1979). Decomposition in terrestrial ecosystems. Berkeley: University of California Press.

Škorić, A., Filipovski, G. \& Ćirić M. (1985). Klasifikacija zemljišta ex. Jugoslavije. Sarajevo: Akademija Nauka i Umjetnosti $\mathrm{BiH}$.

Španjol, Ž., Barčić, D., Seletković, I., Potočić, N. \& Vučetić M. (2010). Monitoring onečišćenja tla uz autocestu Rijeka-Zagreb (Projekt 1). Zagreb: Zavod za ekologiju i uzgajanje šuma, Šumarski fakultet Sveučilišta u Zagrebu.

Špoljar, A. (1999). FAO klasifikacija s bazom podataka za pedološku kartu Republike Hrvatske sitnog mjerila. Magistarski rad, Agronomski fakultet Sveučilišta u Zagrebu, Zagreb.

Tikvić, I. \& Seletković Z. (2003). Utjecaj pošumljavanja krša na hidrološku funkciju šuma. Šumarski List, 127, 31-34.

Topić, V. (1992). Količina i kemizam šumske prostirke pod nekim šumskim kulturama na kršu. Šumarski List, 9-10, 407-414.

Trinajstić, I. (1986). Fitogeografsko raščlanjenje šumske vegetacije istočnojadranskog sredozemnog područja polazna osnovica u organizaciji gospodarenja mediteranskim šumama. Glasnik za Šumske Pokuse, 2, 53-67.

Vitousek, P.M., Gerrish, G., Turner, D.R., Walker, L.R. \& Mueller-Dumbois D. (1995). Litterfall and nutrient cycling in four Hawaiian montane rainforests. J. Trop. Ecol., 11, 189-203. DOI: 10.1017/S0266467400008634.

Vukadinović, V. \& Lončarić Z. (1998). Ishrana bilja. Osijek: Poljoprivredni fakultet Osijek.

Walter, H. (1955). Die Klima-Diagramme als Mittel zur Beurteilung der Klimaverhältnisse für ökologische, vegetationskundliche und landwirtschafliche Zwecke. Berichte der Deutschen Botanischen Gesellschaft, 68, 331-344. DOI: 10.1111/j.1438-8677.1955.tb00850.x.

Wolt, J.D. (1994). Soil solution chemistry-applications to environmental science and agriculture. New York: John Wiley\& Sons. 